ББК 63.4

\author{
Организация конференциии и издание материалов проведень \\ при финансовой поддержке Российского фонда фундаментальных исследований, \\ проект № 19-09-20008
}

Утверждено к печати Ученым советом ИИМК РАН

Редакционная коллегия тома I: В. А. Алёкшин, Л. Б. Кирчо (отв. редакторы),

В. П. Никоноров, В. Я. Стёганцева; В. В. Терёхина

Рецензенты: д. и. н. Л. Б. Вишняцкий, д. и. н. А. А. Выборнов

Программный комитет конференции: академик РАН, д. и. н., проф. М. Б. Пиотровский

(Государственный Эрмитаж, почетный председатель); д. и. н. В. А. Лапшин (ИИМК РАН, председатель); д. и. н. А. В. Головнёв (МАЭ РАН, сопредседатель); д. и. н. В. А. Дергачёв (Высшая антропологическая школа, Молдова, сопредседатель); д. и. н. И. Ф. Попова (ИВР РАН, сопредседатель); академик АН Республики Узбекистан, д. и. н., проф. Э. В. Ртвеладзе (сопредседатель); к. и. н. А. В. Поляков (ИИМК РАН, зам. председателя); к. и. н. В. А. Алёкшин (ИИМК РАН, зам. председателя); д. и. н. Ю. Е. Берёзкин (МАЭ РАН); Dr., Prof. Н. Бороффка (Германский археологический институт, Германия); В. С. Бочкарёв (ИИМК РАН); Dr. Э. Кайзер (Свободный университет Берлина, Германия); к. и. н. М. Т. Кашуба (ИИМК РАН); д. и. н. Л. Б. Кирчо (ИИМК РАН); к. и. н. А. В. Кияшко (Южный федеральный университет); к. и. н. П. Ф. Кузнецов (СГСПУ);

к. и. н. Н. М. Малов (СНИГУ); к. и. н. В. П. Никоноров (ИИМК РАН); Ю. Ю. Пиотровский

(Государственный Эрмитаж); д. и. н., проф. Д. Г. Савинов (Институт истории СПбГУ);

к. и. н. В. Н. Седых (Институт истории СПбГУ); к. и. н. Н. Н. Скакун (ИИМК РАН);

к. и. н. Н. Ф. Соловьёва (ИИМК РАН); к. и. н. А. И. Торгоев (Государственный Эрмитаж); к. и. н. Е. А. Черлёнок (Институт истории СПбГУ)

Организационный комитет конференции: к. и. н. А. В. Поляков (ИИМК РАН, председатель);

к. и. н. В. А. Алёкшин (ИИМК РАН, зам. председателя); В. С. Бочкарёв (ИИМК РАН); ); к. и. н. М. Т. Кашуба (ИИМК РАН); д. и. н. Л. Б. Кирчо (ИИМК РАН);

А. И. Климушина (ИИМК РАН, отв. секретарь); к. и. н. В. П. Никоноров (ИИМК РАН); Ю. Ю. Пиотровский (Государственный Эрмитаж); В. Я. Стёганцева (ИИМК РАН); В. В. Терёхина

(ИИМК РАН, МАЭ РАН, отв. секретарь); к. и. н. Е. С. Ткач (ИИМК РАН); И. Ж. Тутаева (Государственный Эрмитаж); к. и. н. Е. А. Черлёнок (Институт истории СПбГУ)

Древности Восточной Европы, Центральной Азии и Южной Сибири в контексте связей и взаимодействий в евразийском культурном пространстве (новые данные и концепции): Материалы Международной конференции, 18-22 ноября 2019 г., Санкт-Петербург. Т. I. Древняя Центральная Азия в контексте евразийского культурного пространства (новые данные и концепции). К 90-летию со дня рождения патриарха евразийской археологии Вадима Михайловича Массона. - СПб.: ИИМК РАН, Невская Типография, 2019. — 291 с.

ISBN 978-5-907053-34-2

DOI 10.31600/978-5-907053-34-2 


\title{
YAZ CULTURE IN THE SERAKHS OASIS IN TURKMENISTAN ${ }^{1}$
}

\author{
Marcin Wagner \\ Institute of Archaeology, University of Warsaw, Warszawa, Poland
}

DOI: $10.31600 / 978-5-907053-34-2-75-77$

Keywords: Turkmenistan, Serakhs oasis, Yaz culture, Early Iron Age, temple offire, administrative centre.

The Serakhs oasis is located in southern Turkmenistan in the Ahal province. It stretches for ca. $70 \mathrm{~km}$ from north to south and $20-25 \mathrm{~km}$ east to west, covering the sub-delta of the Tedjen river as well as the western part of the Bathyz highland (Оразов 1973:3). The water in the oasis is supplied through a well-developed canal system origins at the right bank of the Tedjen river. The main Salyr-yap canal feeds two irrigation canals, Khan-yap (the eastern canal) and Karaman-yap (the western canal) and Kiči Aga-yap and Ata-yap canals with their many smaller branches (Оразов 1973: 30; Kaim 2008: 130).

In the early 1950's, Russian researchers became interested in the archaeology of Serakhs oasis. A. A. Maruščenko began excavations at one of the largest site in the centre named Old Serakhs, which has a long stratigraphic sequence (Марущенко 1956), while K. A. Adykov carried out an archaeological survey in the area between Old Serakhs and Merv (Адыков 1959). At the same time V. M. Masson conducted his research at site of Yaz Depe in Margiana (Массон 1959), on the basis of which he published the first periodisation of the early Iron Age in Central Asia. A. A. Maruščenko

${ }^{1}$ The archaeological researches were conducted with the support of grants from the Ministry of Science and Higher Education of the Republic of Poland and from the National Science Centre, Poland (NCN) (nos. NN 109093439, UMO-2013/09/B/HS3/04315).

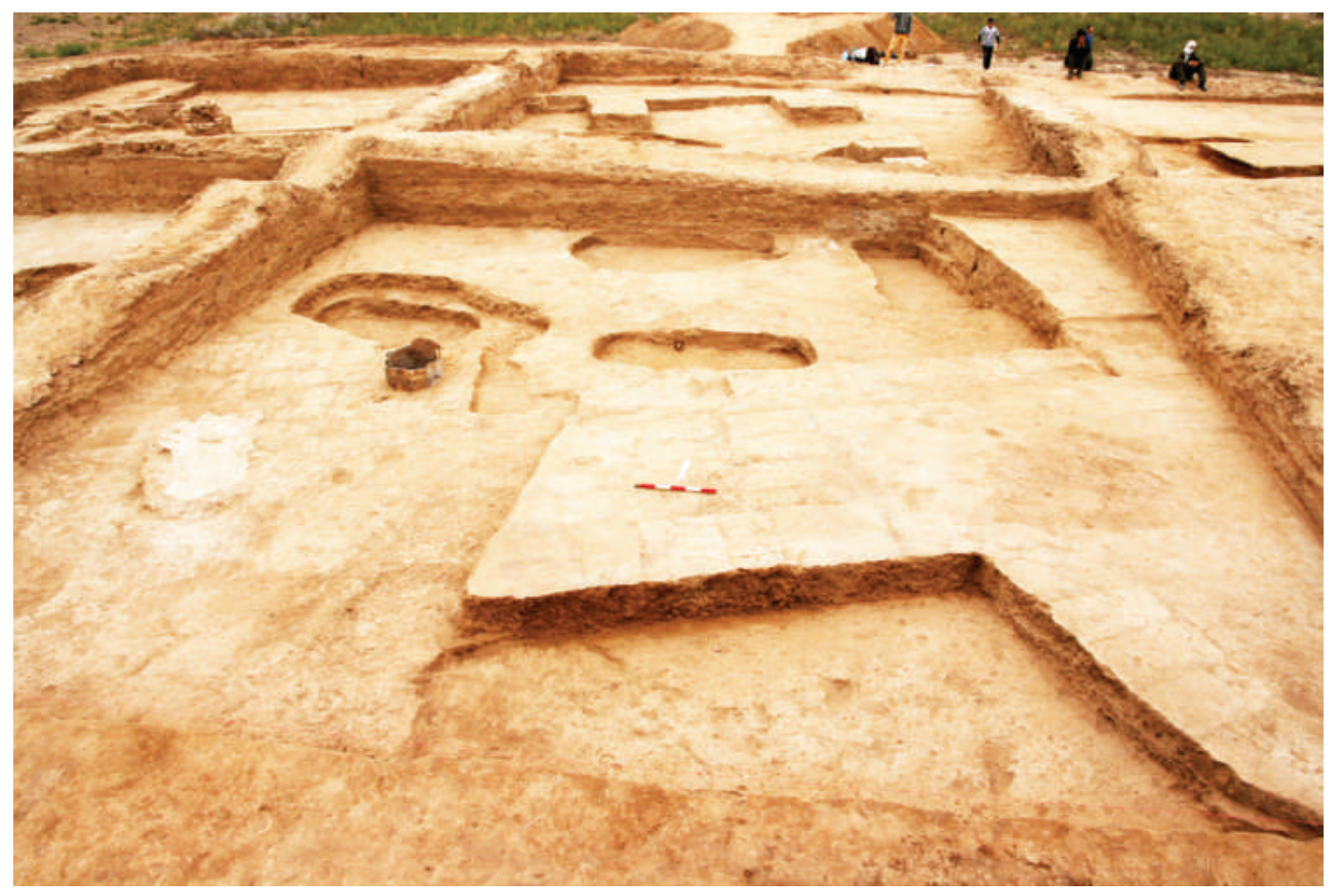

Fig. 1. Topaz Gala Depe, sector D, external wall with a tower, view from south (photo: M. Wagner) 
mentioned in his publication, that a few of pottery sherds dated to the Early Iron Age were found in two trenches (Maruščenko 1956: 173-176, 196-198). It may suggest that the site of Old Seraks was an administrative centre at that time. The second administrative centre named Oyukly Depe, functioned during this time, was situated a little further north. This hypothesis was presented by author after his archaeological work in 2012 (Wagner 2018: 333-334). In the years 1964-1970 O. Orazov carried out excavations and surveys in the oasis. The results of his work became the basis for the first publication of an archaeology in the Serakhs оasis (Оразов 1973). The results of his archaeological research have been verified and complemented by survey conducted in 2007-2008 by Polish researchers (Kaim 2008; Bulavka, Kaim 2016). The results of archaeological works indicate that the settlement of Serakhs oasis is associated with the early Iron Age.

During the excavations at Topaz Gala Depe (Fig. 1) were uncovered remains of fire temple which bears a striking resemblance to a building uncovered in the 1970 s by V. I. Sarianidi in Tillyatepe, northern Afghanistan (Сарианиди 1989). The temple consists of four rooms. The largest room $(13,0 \times 13,9 \mathrm{~m})$ was found in the western part of the building and is divided into rectangular spaces separated by three double cross-walls with pillars between them. The second space counting from the west housed a round clay altar surronded by low square wall. In the SW corner was placed a cracked vessel used for carrying hot ashes from the altar. Two upended vessels were discovered in the eastern part. They were probably meant to replace the damaged vessel found in the SW-corner. The temple was additionally surrounded by a fortified wall with semi-circular towers. Interesting is that the fire temple was erected a considerable distance from other settlements. The calibrated dates $\mathrm{C}^{14}$ of collected samples indicate that the temple functioned in the years 930$745 \mathrm{BC}$. Founding fragment of painted pottery sherds suggest that this site could be existed during the Yaz I period (Wagner 2018).

Two trenches opened at Oyukly Depe provided very numerous fragments of ceramic vessels and simple mudbrick's walls. The size of site and absence of later settlements and surrounding by smaller satellite sites indicate the character of Oyukly Depe as the administrative centre.

An excavations carried out by author at two sites e. g. Topaz Gala Depe and Oyukly Depe provided further information about settlements in this early period.

\section{References}

Адыков К. А. 1959. Главные станции арабских дорожников на средневековом торговом пути из Серахса в Мерв // СА. № 4. С. 212-227.

Марущенко А. А. 1956. Старый Серахс (Отчет о раскопках 1953 г.) // Тр. ИИАЭ АН Туркменской ССР. 2. С. 161-205.

Массон В. М. 1959. Древнеземледельческая культура Маргианы. М.; Л. (МИА. 73).

Оразов О. 1973, Археологические и архитектурные памятники Серахского оазиса. Ашхабад.

Сарианиди В. И. 1989. Храм и некрополь Тиллятепе. М.

Bulavka N. 2017. The Yaz I-III Settlement Pattern in the Serakhs Oasis, Southern Turkmenistan. In: Iran. 55. 2. P. 143-170.

Buławka N., Kaim B. 2016. The Iron Age in Serakhs Oasis (Turkmenistan). The Preliminary Results of the Application of Geographic Information System in the Study of the Settlement Pattern of the Earliest Confirmed Occupation of the Oasis. In: Campana S. Scopigno R. Carpentiero G. Cirillo M. (eds.). CAA 2015. Keep the Revolution Going: Proceedings of the $43^{\text {rd }}$ Annual Conference on Computer Applications and Quantitative Methods in Archaeology. 2. P. 791-801.

Kaim B. 2008. The Parthian Settlements in the Serakhs Oasis. In: Parthica Incontri di Culture Nel Mondo Antico. 10. P. 129-134. 
Wagner M. 2018. The fire temple at Topaz Gala depe in southern Turkmenistan. In: Lhuiller J., Boroffka N. (eds.). A Millennium of History. The Iron Age in southern Central Asia ( $2^{\text {nd }}$ and $1^{\text {st }}$ Millennia BC): Proceedings of the conference held in Berlin (June 23-25, 2014). Dedicated to the memory of Viktor Ivanovich Sarianidi. P. 333-341 (Archäologie in Iran und Turan. 17. Mémoires de la Délégation Archéologique Française en Afghanistan. 35).

\title{
КУЛЬТУРА ТИПА ЯЗ В СЕРАХСКОМ ОАЗИСЕ (ТУРКМЕНИСТАН)
}

\section{М. Вагнер}

Институт археологии Варшавского университета, Варшава, Польша

Ключевые слова: Туркменистан, Серахский оазис, ранний железный век, культура типа Яз, храм огня, административный иентр.

Уже в 1959 г. проф. В. М. Массон, основываясь на своих исследованиях на Яз-депе в Маргиане, опубликовал первую периодизацию железного века в Средней Азии. Почти 50 лет спустя археологи из Института археологии Варшавского университета провели исследования в Серахском оазисе, которые выявили нескольких памятников, относящихся к культуре типа Яз (Bulavka 2017). Польские ученые с 2009 г. проводили раскопки на небольшом холме Топаз Гала депе, расположенном в северо-восточной части Серахского оазиса. Они выявили остатки храма огня, относящегося к периоду Яз II. В 2012 г. были также заложены две траншеи на одном из крупнейших памятников в северной части Серахского оазиса - Оюклы-депе. Эти раскопки дали большое количество керамического материала, относящегося в основном к периоду Яз II.

Исследования советских археологов, а также работы польских ученых показывают, что начало заселения Серахского оазиса могло произойти, самое раннее, во второй половине II тыс. до н. э.

\section{ANCIENT METALWORKING IN SOUTHERN KUHDASHT COUNTY IN LORISTAN: A STUDY OF SMELTING SLAG FROM KHARREHSEE IN THE IRON AGE}

\author{
Sorayya Elikaidehno ${ }^{\star}$, Katayoun Pelasaeidi**, Mohammadamin Emami ${ }^{\star \star \star}$ \\ ${ }^{*}$ Research Center for Conservation and Cultural Relics, Institute of Cultural Heritage \& \\ Tourism Organization, Tehran, Iran; ${ }^{* *}$ University of Culture and Art of Iran, Tehran, Iran; \\ *** Department of Conservation, Art University of Isfahan, Isfahan, Iran
}

DOI: 10.31600/978-5-907053-34-2-77-79

Keywords: archaeometallurgy, slag, iron, metalworking, Lorestan, Southern Kuhdasht, kharrehsee area.

Lorestan has long attracted the attention of archaeologists due to its geographical and strategic location during different periods. Moreover, the discovery of numerous objects made of bronze and iron throughout Lorestan shows that from the $3^{\text {rd }}$ millennium $B C$ to the mid- $1^{\text {st }}$ millennium BC, the trade contacts, cultural relations, and metallurgical industries of this region were quite robust. Despite decades of archaeological research in the region and on its rich metallurgical tradition, no comprehensive field study aimed at examining the history of metal extraction and metallurgical production has yet been accomplished in this region. For this reason, a field survey of the South Kouhdasht district, centered around Botkhaneh Cave was piloted with the aim of compiling evidence of ancient metallurgical activity by identifying the location of concentrations of slags heaps. For recounting the smelting sites many villages in the vicinity were surveyed, in order to assume information from local people to identify the areas where slags might be present. Once sites were located, their dimensions were documented, their features photographed, and slags were 